\title{
H.C. Andersen vs. økokritikken
}

Torsten Bøgh Thomsen: Skyggepunkter. Menneske, natur og materialitet i H. C. Andersens forfatterskab, Forlaget Spring, 2019.

Torsten Bøgh Thomsen er ph.d. og adjunkt ved H.C. Andersen Centret på Syddansk Universitet. I sin nyligt udkomne monografi, Skyggepunkter, kridter han banen op til en både interessant, konfrontativ og diskutabel nylæsning af H. C. Andersens forfatterskab. Læsningerne trækker på aktuel og populær økokritisk teori- og metodetænkning, der fra første halvdel af 2010'erne i stigende grad har vundet indpas i danske litteraturstudier. Bogen er en revideret ph.d.-afhandling, som forfatteren i 2017 forsvarede på H.C. Andersen Centret.

Afhandlingen er, som det sig hør og bør i genren, stærkt tesestyret. Den består, ud over indledning og afrunding, af seks tematiske hovedkapitler med kronologiske læsninger af udvalgte H.C. Andersen-tekster fra hele forfatterskabet i relation til emnerne antropocæn, romantik, natur, ting, videnskab og kunst. Heri udfoldes og afprøves hovedtesen, der vedrører dette, at Andersens forfatterskab præsenterer originale og hidtil oversete overvejelser over forholdet mellem menneske og omverden:

4 Tesen er, at naturen løsrives fra en fastlåst forståelse af den som en samling statiske objekter, der konkret og kunstnerisk kan regnes ud og udnyttes/repræsenteres. Ligeledes bliver den traditionelle forståelse af mennesket som placeret i toppen af et hierarki i eksistensen kompliceret. Det er to tematiske konstanter, der findes fra forfatterskabets debut til og med dets allersidste tekster.

Bogen er velskrevet, klar i mælet og velstruktureret, men undgår ikke at rende ind i en række konceptuelle problemer i præsentationerne af og omgangen med økokritikken, sådan som Bøgh Thomsen forstår den med inspiration fra den texanske professor i engelsk litteratur, Timothy Morton, og den californiske politiske teoretiker og filosof Jane Bennett. De fremhæves flere gange som afhandlingens vigtigste inspirationskilder og garneres tillige med en lind strøm af kommentarer og referencer til fortrinsvis amerikanske nymaterialistiske og økokritiske teoretikere i relation til bogens kritiske opgør med epokale og stilistiske kategorier såsom 'romantik', 'idealisme' og 'modernisme'. 
Afhandlingen har adskillige filosofihistoriske afsnit om idealisme og romantik i perioden fra Kant til Hegel. Den københavnske romantikforsker Marie-Louise Svane citeres således for en påstand om, at romantikernes poesi frem for alt "skulle bane vejen til den anden dimension, den skulle åbne sluserne for dette endnu-ikke-sete, det transbevidste og transreale". Her henviser præfikset 'trans' til tranformation fra en tilstand til en anden, hvilket inspirerer Bøgh Thomsen til følgende betragtning:

6 hvad enten vi taler om Fichte, Herder, Hegel, Goethe, Novalis, Schiller, Heine, Eichendorff eller brødrene Schlegel, så er de (...) fælles om at reagere på tankegods, som henholdsvis Descartes og Kant gjorde gældende: at der findes en adskillelse imellem mennesket og dets omgivelser, som rejser spørgsmål af epistemologisk, ontologisk og metafysisk art. Og når man kan tænke sig frem til en adskillelse, må man også kunne forestille sig en enhed, noget absolut, som ville være foreningen af subjekt og objekt.

Dette lader sig muligvis tænke, men da på en uhyre abstrakt og forskelsudjævnende facon, som i sig selv ikke er særlig kongenial med forskelsbaserede og tingsvibrerende økokritiske tankegange. Der er meget store inkongruente forskelle mellem medlemmerne af Bøgh Thomsens forsamling af romantikere, klassicister, idealister, digtere og filosoffer, der ikke seriøst differentieres, hverken i citatet eller andre steder i bogen. Således mente Fichte, Novalis og Friedrich Schlegel på hver deres måde, at subjekt og objekt kun kan udveksles i en formal og uendelig proces, og ingen af dem medtænkte Descartes eller reflekterede over menneskets forhold til naturen som sådan. Kant annullerede i Kritik der reinen Vernunft Descartes' betydning med sin epokegørende massakre på enhver form for skolastiske gudsbeviser og rationalistiske dogmer om grænseløs fornuftstyring. Desuden var Kants tænkning i den filosofiske idealisme og i den tidlige tyske romantik en epistemologisk og ikke en ontologisk grænseerfaring. Og 'det absolutte' var for mange i gruppen en uendelig (dvs. uindløselig) stræben efter frihed. Hegel dynamiserede forbindelsen mellem subjekt og objekt historiefilosofisk i modsætning både til Kant, de idealistiske filosoffer og de tidlige romantikere. Herder regelsatte den nationalistisk som sekulær åndelig enhedstænkning. En af de få, der til en vis grad kunne falde ind under Bøgh Thomsens transkriterier, er K.W.F Solger, Fichtes professorale efterfølger på Berlin Uni, og hans begreber om ironi, allegori og absolut æstetisk skønhedserfaring, men han er jo ikke medtaget.

Det giver derfor ikke mening, i hvert fald ikke for undertegnede, at foretage en sådan udjævning, heller ikke selv om Bøgh Thomsen efterfølgende justerer den en smule. Den synes mestendels at være et anakronistisk knæfald for Mortons almene teori om romantikerne som det antropocænes avantgarde, som Bøgh Thomsen kalder det, hvilket i det mindste kan begrunde anledningen til sammensætningen af denne problematiske 'romantiske' gruppe, der forunderligt nok inkluderer romantikhaderen Goethe og den klassicistiske dannelsesæstetiker Schiller. 
Afhandlingens måde at kombinere analyse og teori på må siges at være både stærk og svag, som man jo siger. På den ene side er der H.C. Andersen-læsningerne, der præsenteres i en åben og dialogisk form. På den anden side er der de almene og polemiske overvejelser over ontologi, epistemologi og epokalitet, der fremføres i et kategorisk, assertivt og olympisk toneleje.

De tematiserede værkanalyser udmærker sig ved hverken at være kategoriske eller unødigt polemiske, men derimod tænksomme og tekstnære og i god og konstruktiv dialog med værkernes reception i den danske litteraturhistorie fra 1970'erne og frem. Vi kan her fremhæve bl.a. den Morton-inspirerede slim-analyse i Improvisatoren, de perspektivrige analyser af Andersens omgang med ting og overvejelserne over hans anti-idealisme. Også læsningerne af Fodreise og Skyggebilleder er perspektivrige, om end det kan undre, at Bøgh Thomsen overhovedet ikke medtænker de 'splittelsesromantiske' læsninger af og kommentarer til Fodreise og mere sporadisk Skyggebilleder, som en del af os faktisk har bidraget med siden 1980'erne, samt at han ikke kommenterer $\mathrm{fx}$ den negative naturromantik hos Schack Staffeldt eller skrækromantikken hos B.S. Ingemann. Men alt i alt gør analysernes eftertænksomhed og lydhørhed dem stærke og overbevisende, da de i applikationerne af de $\emptyset$ kokritiske perspektiver og dogmer levner dialogisk plads til både H.C. Andersens særegne tænke- og skrivemåder og hans tidligere læseres synspunkter, uden hårdhændede og retarderende ideologiske tilskæringer.

Helt modsat forholder det sig med afhandlingens præsentationer af og rammesættende refleksioner over de efterhånden velkendte økokritiske og nymaterialistiske dogmer. De er absolut relevante at beskæftige sig med, ingen tvivl om det. Men de har det med i aktuel dansk litteraturforskning at bevirke en hårdtslående, alvidende og ikke særlig ‘økologisk' retorik blandt yngre forskere, der uden megen sans for nuancer kategorisk taler hen over egne begrænsninger i viden og indsigt. Denne retorik, der tydeligvis ønsker at være 'stærk' i opgøret med al tidligere litteraturteori og litteraturhistorisk skrivning, må siges at være en svaghed ved afhandlingens hovedkonstruktion.

Den trækker på den ene side på Timothy Mortons teoretiske diskurs, som i en idiosynkratisk, sløset og amerikansk-dekonstruktiv jargon meddeler sine hovedkuldse og kun sjældent gennemtænkte universalistiske teser om 'klima', 'natur', 'romantik' og 'hyperobjekter'. På den anden side trækker den på Jane Bennetts gennemarbejdede og koncise økokritiske, holistiske og stofvibrerende spinozisme og vitalisme. Af de to er det helt klart Morton, der har det store ord at skulle have sagt $i$ afhandlingen.

Bøgh Thomsen diskuterer et par steder kort de store forskelle, der notorisk er mellem disse to forbilleder, men slår sig til tåls med, at de i nogle udvekslinger har talt pænt om hinanden og forfølger derfor ikke forskellene mellem dem yderligere. Han inddrager således ikke Bennetts kritiske svar til Timothy Morton og Graham Harman i det velrenommerede litteraturhistoriske tidsskrift New Literary History \#2, 2012, vedrørende disputter om den objektorienterede filosofi, som tidligt blev et vigtigt element i nymaterialisme og økokritik og som har skabt en del kontrovers. Bøgh Thomsen kunne også have inddraget Harmans opgør, ligeledes i New Literary 
History \#2, 2012, med den såkaldte 'korrelationisme', som med brask og bram (herunder af Harman selv) blev lanceret i OOP (Object-Oriented Philosophy) og senere i OOO (Objekt-Oriented Ontology), da den franske Alain Badiou-elev Quentin Meillassouxs bog Après la finitude (2006) udkom på engelsk i 2010 (den blev totalt forbigået i Frankrig). Hans heuristiske nybegreb om 'korrelationisme' sammenblander på en meget problematisk måde epistemologi og ontologi i en kritik af Kants udelukkende epistemologiske skelnen mellem 'tingen for os' og 'tingen i sig selv', hvilket ad omveje førte til de nymaterialistiske og objektfilosofiske Kantdogmer, som Bøgh Thomsen kritikløst markedsfører som evidente filosofiske udsagn. Han slår endvidere Kants epistemologi i hartkorn med Descartes' begreber om 'res cogitans' og 'res extensa', åbenbart uden at være bekendt med det tidligere nævnte forhold, at Kants epistemologiske kritik af den almene fornuft har til hensigt at problematisere de grænseløse opfølgninger på Descartes' fornuftsbaserede rationalisme hos bl.a. Kants forgænger i lærestolen i Königsberg, Christian Wolff, der dogmatisk fulgte rationalisternes store tiltro til den af Gud, ifølge deres cartesianske grunddogme, i bevidstheden implementerede universelle evne til logisk tænkning og matematiskgeometrisk genbeskrivelse af objektverdenen. Hos både Harman og filosoffen Ray Brassier (Meillassouxs engelske oversætter) og mange andre blev 'korrelationismen' hurtigt parkeret som en filosofisk misforståelse ('rubbish' ifølge Brassier) og Meillassouxs værk følgelig marginaliseret ('korrelationismen' præsenteres og kommenteres kritisk i min artikel om romantisk æstetik efter Kant hos Fr. Schlegel, Novalis og Solger i Ehlers Dam/Stidsen (red.), Distancens patos 2017).

Nævnes her kan også Bøgh Thomsens lige så velsmurte som besynderlige modvilje mod at anerkende og præcisere de i nymaterialistisk regi ofte debatterede og perspektivrige forskelle mellem Bennetts hovedværk Vibrant Matter (2010), Karen Barads procesfilosofiske, feministiske og dekonstruktive kvante- og 'entanglement'teori i Meeting the Universe Halfway (2007) og Donna Haraways feministiske og $\varnothing$ kopolitiske tankegange i fx Staying with the Trouble (2016).

Okay, kunne man så spørge. Er alt dette ikke blot et spørgsmål om forskellige tilgange og fortolkninger? Dertil må svaret være nej. I en ph.d.-afhandling, der baserer sig entydigt på økokritik, må man forvente, at der demonstreres et simpelt og differentieret kendskab til såvel den udskældte Kant og Romantik som de væsentligste af økokritikkens forskellige anliggender, metoder og teorier, som i dag må siges at være velkendte hos toneangivende nymaterialister, økokritikere og posthumanister af både ældre og helt aktuel observans. Udløser dette så metodiske, analytiske og argumentatoriske problemer i strømmen af Andersen-læsninger i Bøgh Thomsens afhandling? Ja, men ikke entydigt negativt.

III

I afhandlingens første hovedkapitel, "Opfindelsen af naturen”, præsenterer Bøgh Thomsen sit metodiske, teoretiske og litteraturpolitiske anliggende med hovedfokus på begrebet 'antropocæn'. Åbningssætningen konstaterer her som også adskillige andre steder i bogen, og altid med henvisning til Timothy Morton, at det er romantikkens naturbegreb, "der ligger til grund for vores senmoderne forståelser af 
naturen og begrebsligt har fjernet den fra mennesket", som der står. Som argument herfor bringes et citat fra Timothy Mortons bog Hyperobjects fra 2013:

Uf The classic image of Nature is the Romantique or picturesque painting of a landscape. There it is, over yonder - on the wall in the gallery. And it has over-yonder-ness encoded throughout it: look at those distant hills, that branch suggesting that we follow the perspective lines toward the vanishing point, and so on.

Bøgh Thomsen vedstår med det samme, at passagen er et "eksempel på Mortons til tider manglende præcision", herunder vedrørende centralperspektivet og den æstetiske distance til naturen, som han rigtigt nok pointerer ikke stammer fra romantikken, men fra renæssancen. Men B $\emptyset \mathrm{gh}$ Thomsen tilslutter sig alligevel Morton ved med reference til den australske økokritiker Kate Rigby at tale om en romantisk genfødsel af denne 'naturarv' fra renæssancen, som i romantikken menes at udfolde sig grænseløst og falde sammen med starten på de teknologiske og industrielle miljøkatastrofer, der i dag rigtig nok er evidente. Andre mere nøgterne opfattelser vil dog næppe gøre klimakrisen til et resultat af romantikkens naturforståelse. Man kan her tænke på Dalia Nassar, hvis studier i det romantiske absolutte i tysk romantisk filosofi Bøgh Thomsen trækker på, men han undgår desværre den af hende redigerede antologi The Relevance of Romanticism (2014), der åbnes med et essay af romantikforskningens ubestridte nestor, Manfred Frank, der har en noget mere nuanceret romantikforståelse end Morton.

Bøgh Thomsen differentierer senere i afhandlingen Mortons abstrakte, galleristiske og unuancerede romantikbegreb ved at minde om den såkaldte 'splittelsesromantik', der beskrives som værende mere i overensstemmelse med økokritikkens dogmer end den universal- og nationalromantik, som han med en vis ret mener har været dominerende i dansk litteratur- og kunsthistorie, og som det er ærindet at dekonstruere ved hjælp af H. C. Andersens ungdomsværker Fodreise og Skyggebilleder.

Afhandlingens åbning lancerer perspektiverne herfor, men undgår at komme ind på dens egen gennemgående brug af universaler og en historiefilosofisk determinisme, hvilket må siges at være noget uigennemtænkt i henhold til økokritikkens forståelse af forbindelserne mellem natur, ting og menneske med baggrund i dens procesfilosofiske impetus, der direkte eller indirekte er influeret af den amerikanske logiker og filosof Alfred North Whiteheads senværk Process and Reality. An Essay on Cosmology (1929), sådan som det er blevet aktualiseret af bl.a. Gilles Deleuze, Bruno Latour, Graham Harman og Isabelle Stengers.

Dette procesfilosofiske aspekt ved nymaterialismen og i økokritikken berører Bøgh Thomsen ikke. Derved fremkommer der nogle uhensigtsmæssige blinde pletter i hans metodik i henhold til Mortons anvendelse af begrebet 'Romantik' som universale. På trods af de relevante revisioner, køber han som sagt blankt Mortons grundpointe om, at 'romantikken' er hovedansvarlig for den antropocæne misere i kraft af dens tiltro til den menneskelige bevidstheds suveræne overlegenhed over for naturen, som den derved kaster under sig og benytter som transcendensfilosofisk selvspejl. Selv om dette vel kun for alvor gør sig gældende for nyplatonistiske panteister og kun halvt, om man så må sige, for fx William Wordsworth, der i "Tintern Abbey" har linjerne 
.. and of all that we behold

From this green earth; of all the mighty world

Of eye, and ear,-both what they half create,

And what perceive;

Romantikkens selvspejling i naturen skulle angiveligt ifølge Morton og Bøgh Thomsen have medført den destruktive adskillelse mellem menneske og natur i en kontinuerlig og katastrofal udvikling fra slutningen af 1700-tallet til i dag. Dette betinger afhandlingens konceptuelle og narrative ramme, der ikke blot trækker på universalet 'Romantik', men også på en afart af historiefilosofisk determinisme i beskrivelsen af udviklingen fra romantikken til nu, det vil sige til vor tids "senmoderne forståelser" af natur-menneske-relationen. Det kan undre, at Bøgh Thomsen ikke terminologisk og konceptuelt overvejer dette kritisk i forhold til den økokritiske holisme og/eller procestænkning, der, som han må forventes at vide alt om, hverken accepterer universaler eller historiefilosofisk tænkning. Heller ikke begrebet 'dialektik', som Bøgh Thomsen ofte anvender, turde være gangbart i en økokritisk diskurs, der har til hensigt anti-dialektisk at dekonstruere traditionelle dikotomier i stil med menneske vs. natur, subjekt vs. objekt, ting vs. bevidsthed, etc.

\section{IV}

Torsten Bøgh Thomsen antyder et sted, at han muligvis selv er klar over ikke at være helt på højde med ontologi og epistemologi i såvel almen kontinentalfilosofi som nymaterialisme og økokritik og udvekslinger derimellem. I hvert fald bemærker han et sted i afhandlingen, at han har et poetologisk fokus på bekostning af ontologikritikken. Forholdet mellem ontologi og poetologi har jeg imidlertid svært ved at forstå som andet end en konceptuel svikmølle. Det virker i hvert fald ikke overbevisende pludselig at udskille poetologien fra ontologien som afhandlingens egentlige ærinde, når det nu engang er den økokritiske ontologikritik og den 'flade ontologi' hos Bennet og Morton, Bøgh Thomsen eksplicit har som ramme for sine postromantiske analyser, der har det med at gøre alle katte grå i dette øko-ontologiske mørkesyn.

Bøgh Thomsen fremstår med andre ord ikke som nogen overbevisende filosofihistoriker/ontologikritiker, men må samtidig siges at være en god og solid læser af H.C. Andersen, hvilket ville have stået endnu stærkere end tilfældet er, hvis han havde nedtonet hele den økokritiske totalentreprise og heuristiske (amerikanske) fantasi om en samlet ontologisk og poetologisk reboot af eurocentrisk litteratur-, filosofi- og kulturhistorie, ved mindre fundamentalistisk blot at have trukket på $\varnothing$ kokritik og nymaterialisme som inspiration og bagvedliggende perspektiv, sådan som han gør det i den spændende analyse af slim i Improvisatoren.

Anmeldt af Jørn Erslev Andersen 